\title{
PROFIL FAKTOR-FAKTOR RISIKO PADA PASIEN STROKE YANG DIRAWAT INAP DI IRINA F NEUROLOGI RSUP PROF. Dr. R. D. KANDOU MANADO PERIODE JANUARI - OKTOBER 2012
}

\author{
${ }^{1}$ Rio Christanto \\ ${ }^{2}$ Corry N. Mahama \\ ${ }^{2}$ Melke J. Tumboimbela
}

\author{
${ }^{1}$ Kandidat Skripsi Fakultas Kedokteran Universitas Sam Ratulangi Manado \\ ${ }^{2}$ Bagian Neurologi Fakultas Kedokteran Universitas Sam Ratulangi Manado \\ Email: riochristanto619@gmail.com
}

\begin{abstract}
Abstrak: Stroke merupakan penyakit neurologi yang serius, dengan serangan akut yang dapat menyebabkan kematian. Terjadinya stroke berkaitan erat dengan faktor risiko yang dipunyai oleh penderita, terutama bila faktor risiko yang ada tidak ditanggulangi dengan baik. Tujuan: Mengetahui profil faktor-faktor risiko pada pasien stroke yang di rawat inap di irina F neurologi RSUP Prof. Dr. R. D. Kandou Manado periode januari 2012 sampai oktober 2012. Metode: Penelitian deskriktif dengan metode retrospektif yaitu mengumpulkan semua data penderita yang telah didiagnosa dengan stroke yang di rawat inap di irina F neurologi RSUP Prof. Dr. R. D. Kandou Manado periode januari 2012 sampai Oktober 2012. Hasil: Hasil penelitian menunjukan bahwa persentase terbanyak pasien stroke berada pada golongan umur 51-65 tahun (45,2\%), berjenis kelamin laki-laki (51,2\%), kategori risiko tinggi hipertensi $(92,2 \%)$, kategori risiko rendah dislipidemia $((73,1 \%)$, risiko rendah diabetes melitus $(83,8 \%)$, riwayat atau kelainan jantung (40,2\%), memiliki riwayat merokok (8,2\%). Simpulan: Terdapat 3 faktor risiko yang berpengaruh terhadap kejadian stroke yaitu umur, jenis kelamin dan hipertensi
\end{abstract}

Kata kunci: Stroke, faktor risiko

\begin{abstract}
Stroke is a serious neurological disease, with acute attacks that can lead to death. Closely related to the occurrence of stroke risk factors possessed by the patient, especially if there are risk factors that are not addressed properly. Aim: To know the profile of risk factors in stroke patients hospitalized in neurology. irina $F$ of RSUP Prof. Dr. R. D. Kandou Manado among period january to october 2012. Methods: The study descriptive with retrospective method is to collect all the data of patients who had been diagnosed with stroke in inpatient neurology irina F RSUP Prof. Dr. R. D. Kandou Manado among period january to october 2012. Results: The results showed that the highest percentage of stroke patients are in the age group 51-65 years (45.2\%), male sex (51.2\%), high risk category of hypertension (92.2\%), risk category Low dyslipidemia ((73.1\%), low risk of diabetes mellitus (83.8\%), history of heart problems (40.2\%), had a history of smoking (8.2\%). Conclusion: There are three factors that influence the risk of stroke incidence is age, gender and hypertension
\end{abstract}

Keywords: stroke, risk factors

Definisi stroke menurut WHO adalah manifestasi klinik dari gangguan fungsi serebral baik fokal maupun menyeluruh (global), yang berlangsung dengan cepat, berlangsung lebih dari 24 jam, atau berakhir dengan maut, tanpa ditemukan penyebab selain dari gangguan vaskular. ${ }^{1}$

Stroke merupakan penyakit neurologi yang serius, dengan serangan akut yang dapat menyebabkan kematian dalam waktu 
singkat ataupun kecacatan seumur hidup. Penelitian berskala cukup besar dilakukan oleh ASNA (Asean Neurologic Association) di 28 Rumah Sakit di seluruh Indonesia. Penelitian ini dilakukan pada penderita stroke akut yang dirawat di Rumah Sakit (hospital based study) dan dilakukan survey mengenai faktor-faktor risiko, lama perawatan dan mortalitas serta morbiditasnya. Hasilnya menunjukkan bahwa penderita laki-laki lebih banyak dari perempuan dengan profil usia di bawah 45 tahun cukup banyak yaitu $11,8 \%$, usia $45-64$ tahun berjumlah $54,7 \%$ dan di atas usia 65 tahun $33,5 \%{ }^{2}$

Terjadinya stroke berkaitan erat dengan faktor risiko yang dipunyai oleh penderita. Faktor-faktor risiko stroke di bagi menjadi dua, yaitu faktor risiko yang tidak dapat dimodifikasi (seperti umur, ras, jenis kelamin, genetik) dan faktor risiko yang dapat dimodifikasi (seperti hipertensi, kelainan jantung, diabetes, dislipedemia, merokok, obesitas). ${ }^{3}$

Seseorang yang memiliki faktor risiko stroke memiliki kecenderungan mengalami serangan stroke, terutama bila faktor risiko yang ada tidak ditanggulangi dengan baik. Karena itu perlu diupayakan prevensi yang meliputi gaya hidup sehat dan pengendalian faktor risiko, yang bertujuan mencegah terjadinya serangan stroke. Dengan pertimbangan hal-hal diatas perlu dilakukan penelitian tentang profil beberapa faktor risiko pada pasien stroke (baik faktor risiko yang tidak dapat dimodifikasi maupun faktor risiko yang dapat dimodifikasi).

\section{METODE PENELITIAN}

Penelitian ini merupakan metode deskriptif retrospektif, yang dilakukan di Irina F Neurologi RSUP Prof. Dr. R. D. Kandou Manado selama kurang lebih 2 bulan yaitu dari bulan November 2012 sampai dengan bulan Desember 2012. Populasi penelitian ini terdiri dari semua penderita stroke yang dirawat inap di Irina F Neurologi RSUP Prof. Dr. R. D. Kandou Manado periode Januari 2012 sampai Oktober 2012 yang didiagnosis oleh dokter spesialis saraf sebagai stroke berdasarkan riwayat penyakit, pemeriksaan neurologi, pemeriksaan penunjang yang tercatat dalam rekam medis. Sampel penelitian ini semua data penderita yang telah didiagnosa dengan stroke yang berjumlah 281 pasien dan dirawat inap di irina $F$ Neurologi RSUP Prof. Dr. R. D. Kandou Manado periode Januari 2012 sampai Oktober 2012.

\section{HASIL PENELITIAN}

Data mengenai kasus stroke periode Januari hingga Oktober 2012 menunjukkan adanya peningkatan dan penurunan kasus di tiap bulannya. Bulan Januari terdapat 31 kasus, Februari 21 kasus, Maret 16 kasus, April 21 kasus, Mei 40 kasus, Juni 27 kasus, Juli 25 kasus, Agustus 39 kasus, September 36 kasus dan Oktober 25 kasus.

Distibusi pasien stroke menurut umur ditemukan paling banyak penderita berumur 51-65 tahun dengan persentase $45,2 \%$.

Data mengenai jenis kelamin paling banyak penderita stroke berjenis kelamin laki-laki sebanyak 51,2\%.

Pada distribusi frekuensi faktor resiko dislipidemia pada pasien stroke didapatkan pasien dengan resiko rendah dislipidemia sebanyak 73,1\% dan resiko tinggi dislipidemia sebanyak 26,9\%.

Distribusi frekuensi faktor resiko DM pada pasien stroke ditemukan resiko rendah sebanyak 83,8\% dan pasien resiko tinggi sebanyak 16,2\%.

Pada distribusi frekuensi penyakit jantung pada pasien stroke sebanyak 59,8\% tidak memiliki riwayat atau kelainan jantung sedangkan sebanyak 40,2\% memiliki riwayat atau kelainan jantung.

Data mengenai kebiasaan merokok pada pasien stroke ditemukan sebanyak 91,8\% tidak memiliki riwayat merokok atau tidak tercatat dalam rekam medik sedangkan 8,2\% memiliki riwayat merokok.

\section{BAHASAN}

Pasien stroke rawat inap di irina $\mathrm{F}$ Neurologi RSUP Prof. Dr. R. D. Kandou Manado periode Januari sampai Oktober 2012 lebih banyak berada pada golongan 51 
- 65 tahun. Hal ini memberikan gambaran bahwa pola penyakit stroke cenderung terjadi pada golongan umur yang lebih tua tapi masih produktif. Berbagai penelitian lain juga menunjukan bahwa distribusi penderita menurut kelompok umur ditemukan pada penderita lebih dari 40 tahun dan paling banyak berada pada golongan 51- 65 tahun yaitu sebanyak 74 orang (49\%). ${ }^{4}$

Pada penelitian ini dapat dilihat penderita laki-laki lebih banyak dari penderita perempuan, namun tidak terjadi perbedaan proporsi yang berarti. Dari 281 pasien stroke rawat inap di irina F Neurologi RSUP Prof. Dr. R. D. Kandou Manado periode Januari sampai Oktober 2012, sebanyak 144 pasien (51,2\%) berjenis kelamin laki-laki dan 137 pasien (48,8\%) berjenis kelamin perempuan. Pada dasarnya stroke lebih sering terjadi pada jenis kelamin laki-laki dibandingkan perempuan. Hal ini disebabkan karena perempuan lebih terlindungi dari penyakit jantung dan stroke sampai umur pertengahan akibat hormon estrogen yang dimilikinya. Akan tetapi pada penelitian ini didapatkan umur pasien berjenis kelamin perempuan diatas 50 tahun lebih banyak dari pasien perempuan usia pertengahan. Hal ini menunjukan bahwa setelah mengalami menopouse risiko perempuan sama dengan laki-laki untuk terkena serangan stroke. Banyak wanita menopouse dikanada meninggal akibat serangan Stroke dan penyakit jantung pada setiap tahunnya. ${ }^{5,6}$

Hipertensi merupakan faktor risiko utama pada penyakit stroke, baik tekanan sistolik mauun tekanan diastoliknya yang tinggi. ${ }^{7}$ Dalam penelitian framingham didapatkan bahwa kejadian stroke lebih tinggi pada orang yang hipertensi berat (tekanan darah lebih tinggi dari 160/95mmHg) dibandingkan orang yang normotensi (tekanan darah kurang dari 140/90mmHg). Semakin tinggi tekanan darah seseorang, maka semakin besar risiko untuk terkena stroke. $^{5}$

Walaupun secara teoritis, kadar kolesterol total dan LDL yang tinggi serta HDL yang rendah dalam darah dapat meningkatkan risiko stroke. Akan tetapi, menurut hasil penelitian ini diketahui bahwa dari 234 pasien yang diperiksa kadar kolesterolnya sebanyak 63 pasien (26,9\%) termasuk dalam kategori risiko tinggi, sedangkan 171 pasien (73,4\%) termasuk dalam kategori risiko rendah. Hasil penelitian pada Framingham Study juga menyebutkan bahwa tidak ada hubungan antara kadar kolesterol yang tidak normal dengan kejadian stroke baik pada laki-laki maupun wanita. ${ }^{5}$ hal ini mungkin disebabkan oleh kadar kolesterol yang tidak normal merupakan salah satu faktor risiko yang lemah untuk memicu terjadinya stroke. ${ }^{7}$

Pada hasil penelitian ini didapatkan bahwa dari 234 pasien yang melakukan pemeriksaan kadar gula darah, sebanyak 38 pasien $(16,2 \%)$ tergolong dalam penderita stroke dengan diabetes melitus dan sebanyak 196 pasien (83,8\%) tergolong dalam penderita stroke dengan diabetes melitus. Dari berbagai penelitian ditemukan bahwa orang dengan diabetes melitus memiliki risiko untuk menderita stroke lebih besar dibandingkan orang yang tidak memiliki riwayat diabetes melitus, karena dapat memicu terjadinya aterosklerosis lebih cepat dibandingakan orang yang tidak menderita diabetes melitus. ${ }^{5}$ Akan tetapi, pada penelitian ini menunjukan bahwa proporsi pasien stroke dengan diabetes melitus lebih kecil dibandingkan pasien stroke tanpa diabetes melitus. Hal ini menunjukan bahwa proporsi orang yang terkena serangan stroke akibat diabetes melitus tidak banyak, artinya sebagian besar pasien mendapatkan serangan stroke bukan karena memiliki diabetes melitus.

Pada penelitian ini didapakan bahwa dari 94 pasien stroke rawat inap di irina $F$ Neurologi RSUP Prof. Dr. R. D. Kandou Manado periode Januari sampai oktober 2012, sebanyak 113 pasien (40,2\%) memiliki riwayat penyakit jantung dan sebanyak 168 pasien $(59,8 \%)$ tidak memiliki riwayat penyakit jantung. Hal ini menunjukan bahwa proporsi pasien stroke dengan penyakit jantung lebih sedikit dibandingan dengan pasien stroke yang tidak memiliki penyakit jantung. Hasil penelitian ini serupa dengan hasil sebelumnya, seperti pada 
penelitian di Rumah Sakit Krakatau Medika Tahun 2011 dari 152 penderita stroke, persentase penderita stroke dengan riwayat penyakit jantung adalah sebanyak 25 orang (16\%) sedangkan yang tidak memiliki riwayat penyakit jantung sebanayak 127 orang $(84 \%) .{ }^{4}$

\section{SIMPULAN}

Hasil penelitian pada pasien stroke rawat inap di Irina F Neurologi RSUP Prof. Dr. R. D. Kandou Manado periode Januari sampai Oktober 2012, menunjukan bahwa pasien dengan faktor risiko hipertensi (92,2\%), jenis kelamin laki - laki (51,2\%), umur 51 - 65 tahun (45,2\%), kelainan jantung (40,2\%), dislipidemia (26,9\%), diabetes melitus $(16,2 \%)$ dan kebiasaan merokok (8,2\%).

\section{DAFTAR PUSTAKA}

1. Harsono. Kapita Selekta Neurologi. Edisi 2. Yogyakarta: Penerbit Buku Gadjah Mada
University Press; 2009. Hal. 81-99.

2. Misbach J, Wendra A. Stroke in Indonesia. A first large prospective. Hospital base study of acute stroke in 28 hospitals in Indonesia. Stroke Society of Australia Annual Scientific Meeting in Singapore; 1997.

3. Meifi, Darmadi Agus. Stroke dan depresi pasca stroke. Diunduh dari http:// www.isjd.pdii.lipi.go.id/admin/jurnal/81091 726. [Diakses tanggal 12 oktober 2012]

4. Dian Nastiti. Gambaran Faktor Resiko Kejadian Stroke Pada Pasien Stroke Rawat Inap Di Rumah Sakit Krakatau Medika Tahun 2011. Depok: Fakultas Kesehatan Masyarakat Universitas Indonesia; 2004.

5. Pearson, Thomas A. Primer In Preventive Cardiologi. Texas: American Heart Association; 1994.

6. Heart And Stroke Foundation. A Perfect Strorm Of Heart Disease Looming On Our Horizon. Diunduh dari http://heartandstroke. com [Diakses tanggal 20 desemberr 2012].

7. Lumbantobing SM. Neurogeriatri. Jakarta: Balai Penerbit FKUI; 2011. Hal 93-134. 